\begin{tabular}{|l|l|l||}
\hline \multicolumn{2}{|c|}{ PublisherInfo } \\
\hline \hline PublisherName & $:$ & BioMed Central \\
\hline \hline PublisherLocation & $:$ & London \\
\hline \hline PublisherImprintName & $:$ & BioMed Central \\
\hline \hline
\end{tabular}

\title{
Anaesthetics and hypothermia reduce damage following cerebral ischaemia
}

\begin{tabular}{|l|l|l||}
\hline \multicolumn{2}{|c|}{ ArticleInfo } \\
\hline \hline ArticleID & $:$ & 4206 \\
\hline \hline ArticleDOI & $:$ & $10.1186 /$ ccf-2000-5399 \\
\hline \hline ArticleCitationID & $:$ & 5399 \\
\hline \hline ArticleSequenceNumber & $:$ & 65 \\
\hline \hline ArticleCategory & $:$ & Paper Report \\
\hline ArticleFirstPage & $:$ & 1 \\
\hline \hline ArticleLastPage & $:$ & 3 \\
\hline \hline & & RegistrationDate : 2000-6-14 \\
\hline ArticleHistory & $:$ & OnlineDate \\
\hline \hline ArticleCopyright & $:$ & Current Science Ltd2000-6-14 \\
\hline \hline ArticleGrants & $:$ & \\
\hline \hline ArticleContext & $:$ & 1305422 \\
\hline \hline
\end{tabular}




\title{
Keywords
}

\author{
Neuroprotection, NMDA
}

\section{Comments}

The findings of this interesting study support the evidence that neuroprotection afforded by anaesthetic agents is a specific feature of the agent. It seems increasingly likely that burst suppression or reduction in metabolic rate is not the end of the story. Therapeutic concentrations of both isoflurane and thiopentone had similar effectiveness in increasing the proportion of undamaged cells following anoxia from $(70 \%$ to in excess of $90 \%)$. Further tests showed that glutamate-induced neuronal damage was prevented by isoflurane. This inhibition most probably occurs at the N-methyl D-aspartate (NMDA) receptor. This study provides another strand of evidence that may bring about a better understanding of why anaesthetic agents are neuroprotective and thus lead to improved strategies for neurosurgical procedures. What needs to be investigated is whether the use of thiopentone or isoflurane, shortly after the anoxic insult, can attenuate cell death. This would then have implications for the prevention of secondary injury for head-injured patients.

\section{Introduction}

Intravenous and inhaled anaesthetic agents have been shown to have neuroprotective actions. Volatile agents reduce glutamate-receptor-mediated calcium influx, reduce ischaemia-induced glutamate release, and reduce the activity of NMDA-type glutamate receptors. These actions have not been fully investigated and the relative protection afforded by hypothermia, isoflurane or thiopentone has not been examined. This study uses hippocampal slices rather than cultured cells and looks directly for cell damage and death, which gives it increased validity. Other papers on the subject have looked at raised intracellular calcium or recovery of neurotransmission as surrogates of cell damage.

\section{Methods}


. Controlled in vitro study using rat hippocampal slices

Slices subjected to 10 or $20 \mathrm{~min}$ period of anoxia followed by $5 \mathrm{~h}$ recovery period

. Treatments included altered temperature of the artificial cerebrospinal fluid (34?C, 37?C or 40?C), sodium thiopentone added to the bath $(50 \mu \mathrm{M})$, isoflurane $(0.7 \%$ or $2 \%)$, MK801 (an NMDA receptor blocking agent) and a sham group without anoxia

. Further investigation consisted of bathing slices in glutamate, glutamate plus MK801 and glutamate plus isoflurane $2 \%$

. Following recovery, the slices were fixed in formaldehyde and examined microscopically. The percentage of dead or damaged neuronal cells within a fixed area was examined.

\section{Results}

There were differences within neuron subgroups as to the level of damage. CA1 neurons showed most sensitivity to damage and hence these cells were studied to assess treatment outcome.Mild hypothermia (34?C) reduced damage in all three groups, whereas hyperthermia caused an increase in damage. Swelling and death of CA1 neurons were completely prevented by MK801.Isoflurane $(0.7 \%$ or $2 \%$ ) or thiopentone reduced cell death and damage by a similar amount.Glutamate-induced cell death was prevented by MK801 and isoflurane.

\section{References}

1. Popovic R, Liniger R, Bickler PE: Anesthetics and mild hypothermia similarly prevent hippocampal neuron death in an in vitromodel of cerebral ischemia. Anesthesiology. 2000, 92: 1343-1349. 